called upon to reproduce natural environments of various types. Perhaps a snow scene is one of the most difficult to construct, and its realism is often marred, not least by streaks of dust. In the December 1950 issue of the Museums Journal, W. T. Stirling, of the Royal Scottish Museum, Edinburgh, describes, with operational details, a method by which 'snow' is made from paraffin wax. Molten wax is sprayed with considerable force on to the surface of cold water contained in a large sink, and from a distance which confines the wax particles to the water surface. The accumulating solidified particles are periodically removed and placed in a fine-meshed sieve to drain. Finally they are heaped on to the exhibit. This method obviates any surplus wax on the specimens or the case, and has the advantage that the 'snow' may be arranged in any way, and may be re-arranged if soiled by dirt. The characteristic sparkle may be obtained by liberally. sprinkling with thinly blown and finely fractured glass.

\section{Heriot-Watt College, Edinburgh: Award of Fellowships}

THE governors of the Heriot-Watt College, Edinburgh, have instituted a new award, namely, fellowship of the College, designed primarily to encourage original work in those branches of study at present recognized for the associateship of the College, namely, mechanical and electrical engineering, applied chemistry, mining engineering, brewing and fermentation industries. The fellowship is open to $(a)$ an associate of the College of not less than five years standing, who presents a thesis embodying the results of original research carried out since leaving the College; $(b)$ associates or others holding equivalent qualifications, who complete a period of advanced study in the College and present a thesis. The governors of the College also have powers to confer the honorary fellowship on persons distinguished in science or engineering connected with the College. It is hoped that the institution of this award will in due course give an impetus to the extension of the research activities and higher technological training in the College, and so enable it to play an everincreasing part in developing industrial productivity.

On July 10, the Lord Provost of the City of Edinburgh, the Right Hon. James Miller, conferred the honorary fellowship of the College on the following old students, former members of staff and governors of the College: John M. Caldwell, general manager, Scottish Oils, Ltd. ; Prof. Raymond G. H. Clements, emeritus professor of highway engineering, Imperial College, University of London; Major-General David R. Duguid ; Dr. Charles Forrester, deputy chief fuel engineer, Ministry of Fuel and Power; Prof. James Greig, William Siemen's professor of electrical engineering, King's College, University of London ; Wm. Hamilton Gray, senior partner with the firm of McKerrell Brown \& Gray; Prof. Alex. R. Horne, emeritus professor of mechanical engineering, HeriotWatt College; Dr. Edward Hughes, vice-principal, Brighton Technical College; J. Morison Inches, managing director of J. \& J. Morison, Ltd. ; Peter Kerr, technical secretary of the Institute of Petroleum; Henry R. King, production director, Scottish Division, National Coal Board; James M. Mackintosh, formerly organizer of further education under Edinburgh Corporation Committee; Dr. Wm. Maxwell, until 1949 managing director of Messrs. R. \& R. Clark, Ltd.; Dr. Christina C. Miller, lecturer in chemistry, University of Edinburgh; Dr. David
Penman, formerly principal, Indian School of Mines ; Dr. John S. Penman, vice-principal, Barnsley Technical College; Dr. Willison B. Peutherer, manager, Grangemouth Refinery, Scottish Oils, Ltd. ; Dr. James Sandilands, assistant professor, HeriotWatt College; Roderick M. Shearer, formerly head of the Mathematics Department, Heriot-Watt College; Dr. James Cameron Smail, emeritus principal, Heriot-Watt College; Dr. Alex. M. Smith, head of the Department of Chemistry, College of Agriculture, Edinburgh; Dr. John B. Tait, senior principal scientific officer, Marine Laboratory, Scottish Home Department, Aberdeen; Dr. J. Albert Thomson, chairman and managing director, Brown Bros., Ltd., London; Wm. Watson, formerly head of the Physics Department, Heriot-Watt College ; Robert Wilson, director, Pillans \& Wilson, Ltd.

\section{National Radio Exhibition}

THE term 'Radiolympia' has in the past become well known to all those who are interested in the exhibition organized and held in London under the auspices of the Radio Industry Council. This year, circumstances have necessitated a change of name to that of National Radio Show, and it will be held at Earls Court during August 29-September 8. In connexion with this exhibition, a very interesting and well-produced booklet has recently been issued by the above Council. It is entitled "British Radio and Television for the World-London 1951"; and is intended to interest the overseas reader who will be visiting Great Britain in connexion with one or other of the several exhibitions being held in the early autumn of this Festival of Britain year. The contents of the booklet deal with the current state and trends of technical development in the fields of television, radio and sound reproduction, communications and navigational aids, electronics, including equipment for industrial, medical and scientific purposes, and with valves, cathode ray tubes, components and accessories. All these subjects are illustrated by many interesting photographs, including views of the Birmingham television installation and an associated relay station, the sound-reproducing arrangements in the new House of Commons and, literally, a thimbleful of sub-miniature valves. Copies of the hooklet are obtainable on application to the Secretary, Radio Industry Council, 59 Russell Square, London, W.C.1.

\section{Royal Meteorological Society: Officers}

THE following have been elected officers of the Royal Meteorological Society for the year 1951-52 : President, Sir Charles Normand; Vice-Presidents, Wing-Commdr. Poulter, Dr. R. C. Sutcliffe, Sir Robert Watson-Watt, W. M. Witchell; VicePresident for Canada, A. Thomson; Vice-President for Scotland, Sir Ernest Wedderburn; Secretaries, Prof. P. A. Sheppard, R. G. Veryard; Treasurer, Prof. G. C. McVittie ; Editor, Prof. P. A. Sheppard. The new session will begin on October 1 .

\section{University of London: Appointments}

THw following appointments have been made in the University of London : Dr. K. A. Hirsch, to the University readership in mathematics tenable at Queen Mary College; Mr. J. K. T. L. Nash, to the University readership in civil engineering tenable at King's College; Dr. Stanley Rowlands, to the University readership in physics tenable at St. Mary's Hospital Medical School. 